\title{
The Paraguayan Chaco at a crossroads: drivers of an emerging soybean frontier
}

\author{
James Henderson $^{1}$ (D) Javier Godar ${ }^{2} \cdot$ Gabriel Ponzoni Frey ${ }^{1} \cdot$ Jan Börner ${ }^{1,3} \cdot$ Toby Gardner $^{2}$
}

Received: 10 August 2020 / Accepted: 18 June 2021 / Published online: 2 July 2021

(C) The Author(s) 2021

\begin{abstract}
Our study analyzes potential agro-industrial soybean expansion dynamics and is the first to project soybean expansion Paraguayan Chaco. This biodiverse region, home to the greatest diversity of indigenous groups in Paraguay, has recently seen some of the world's highest deforestation rates, losing 3.4 Mha of forestland between 2001 and 2014. Soy, a globally traded commodity crop and Paraguay's largest export product, recently arrived in the area and may exacerbate the high deforestation rates currently attributed to pastureland expansion. We combine extensive field, trade, and satellite data, to analyze the context, and push-pull factors that are driving frontier expansion dynamics, and assess the potential impacts of soybean-based land use change using geo-located accounts of current soybean production sites. Our analysis finds that roughly 742,000 ha in the Paraguayan Chaco are suitable for soybean frontier expansion with an additional 940,000 ha moderately suitable for expansion. We identify the main drivers of soybean expansion in the region as agricultural technology and land price appreciation. However, infrastructure investments are set to further drive soybean expansion dynamics and connect the region via navigable rivers and roads with access to ports on the Atlantic and Pacific oceans as part of the multi-national Corredor-Bioceánico "bi-oceanic corridor" road project. The continued rapid development of this fragile landscape could transform the Paraguayan Chaco into a major South American logistics hub for soybean and other agricultural production. Without appropriate governance systems in place, this development could lead to irreversible large-scale damage to the socio-environmental systems, similar to boom dynamics seen in other South American frontiers.
\end{abstract}

Keywords Land use change · Agricultural frontier · Soybean expansion · Paraguay · Gran Chaco

\section{Introduction}

The production of agricultural commodities destined for global markets is one of the most important drivers of land use/ land cover change (LULC) in tropical and subtropical regions (Pendrill et al. 2019). As demand for agricultural commodities increases, pressure to expand production to new regions has

Communicated by Jasper van Vliet

James Henderson

jhenders@uni-bonn.de

1 Center for Development Research (ZEF), Rheinische Friedrich-Wilhelms-Universität Bonn, D-53113 Bonn, Germany

2 Stockholm Environment Institute, Stockholm, Sweden

3 Institute for Economics of Sustainable Land Use and Bioeconomy, Rheinische Friedrich-Wilhelms-Universität, Bonn, Germany grown significantly (Lambin and Meyfroidt 2011). Commodity crops rely on large-scale, input-intensive, and highly mechanized production methods that affect the environment, livelihoods, and social structures in production regions (Meyfroidt et al. 2014). Commodity crop expansion can promote economic growth and infrastructure development in new regions and can also result in negative consequences such as deforestation, habitat loss, land consolidation, and loss of livelihoods due to competition with traditional agricultural systems (Baumann et al. 2016; Le Polain de Waroux et al. 2017).

In South America, the expansion of agro-industrial commodities started decades ago in regions with fertile soil and access to markets, beginning in the Atlantic forest and Pampas biomes, gradually expanding further inland towards forested areas with less expensive and more abundant land in the Amazon, Cerrado, Chiquitania, and increasingly the Gran Chaco region (Nolte et al. 2017; Turzi 2017). This trend is particularly prevalent in the soybean sector, either through 
direct expansion into forest areas, or indirectly by displacing other agricultural activities-most notably cattle pastureland - to more marginal or forested areas (Gasparri et al. 2016). These marginal expansion areas often exhibit poor governance systems and/or weak enforcement of socioenvironmental regulations (Eufemia et al. 2020; Le Polain de Waroux et al. 2016).

Significant research on recent South American agricultural frontier expansion has focused on state-driven, smallholderbased colonization or pastureland expansion, particularly in the Amazon region, which reflect a set of drivers and conditions that are less applicable to commercial cropland frontier regions found elsewhere on the continent (Le Polain de Waroux et al. 2018). Research on the dynamics behind the spread and growth of agro-industrial production to new regions often focuses on specific impacts of frontier expansion, such as deforestation (Morton et al. 2006), habitat loss (Ochoa-Quintero et al. 2015), and change in hydrological cycles (Lima et al. 2014). Other studies focus on underlying drivers and conditions that contribute to agricultural frontier expansion (Angelsen 2010; Jepson 2006; Le Polain de Waroux et al. 2017; Le Polain de Waroux et al. 2018), as well as the role of specific actor types (Godar et al. 2014; Pacheco 2012) engaged in frontier expansion. These studies draw on a wide spectrum of theories and empirical methods from various disciplines that inform our conceptualization of modern agricultural frontiers. Comparatively few studies address nonAmazonian land conversions in subtropical regions of South America focusing on specific biomes (Le Polain de Waroux et al. 2018), while others have focused on the impacts of specific land uses (Fehlenberg et al. 2017) in these regions. Several studies consider the drivers and dynamics of agricultural expansion in the Argentine Chaco (Gasparri et al. 2015; Piquer-Rodríguez et al. 2018; Volante et al. 2016) and the Gran Chaco region as a whole (Kuemmerle et al. 2017; Le Polain de Waroux et al. 2018). Still, a research gap remains in the understanding of how the drivers and conditions of agricultural expansion affect commercial cropland frontiers in different non-Amazonian subtropical regions in South America and the role different types of stakeholders play in this expansion, thereby hampering effective decision-making for sustainability in agricultural frontier regions.

Our study looks at the Paraguayan Chaco, a fragile and biodiverse region in South America that has become a deforestation hotspot (Hansen et al. 2013), having lost over $27 \%$ of original forest cover in the years 1987-2010 (Baumann et al. 2016). The potential impact of recently observed soybean expansion is largely absent from recent studies (Baumann et al. 2017b; Le Polain de Waroux et al. 2018), as well as land use change projections originating from civil society (WWF 2016), all of which focus on the impacts of pastureland expansion as the dominant driver of deforestation in the region. The combination of these factors, in addition to infrastructure and accessibility projects currently underway in the region, creates conditions that could lead to soybean and other cropland expansion playing a major role in contributing to LULC in the near future. This includes improvement of current roads connecting the area with the rest of the country, as well as the multi-national Corredor Bioceánico "bi-oceanic corridor" project that will connect the region to $52 \%$ of the world's soybean production, and navigable rivers and ports in the Pacific Ocean by 2022 (Paraguayan Ministry of Public Works and Communications 2020; Ultima Hora 2019). This setting provides a unique opportunity to study the factors and incipient drivers at play in a newly formed and capitalized soybean frontier before an anticipated boom (ABC Color 2020).

Hence, our study will analyze the potential for the Paraguayan Chaco to become a large-scale soybean production region by (1) identifying the drivers and conditions that have led to soybean uptake and incipient expansion and (2) assessing where and to what extent soybean production could expand in the region. Information from these analytical steps informs our discussion of how the Paraguayan Chaco may become both a production and logistics hub for the entire South American soybean sector.

\section{Background/study area-the Paraguayan Chaco}

The Paraguayan Chaco constitutes 24 Mha of the 110 Mha Gran Chaco region, along with territory in Bolivia, Argentina, and a small part of Brazil (Veit and Sarsfield 2017). Together, the Gran Chaco is one of the largest forested regions in South America, along with Amazonia and the Cerrado. In Paraguay, the administrative Chaco region ${ }^{1}$ constitutes roughly $60 \%$ of Paraguay's total land area yet is home to less than $2 \%$ of the country's 7 million inhabitants (Veit and Sarsfield 2017).

Until the late $1800 \mathrm{~s}$, the Paraguayan Chaco was inhabited by roughly 12 semi-nomadic indigenous groups, isolated from foreign influence and with marginal contact with national government structures (Kleinpenning 1983). After Paraguay's defeat in the Triple Alliance war of 1870, large tracts of land were sold to wealthy, mostly foreign, landowners as a way to raise money or in exchange for repaying large war debts (Vázquez 2013). The most consequential changes in land ownership in the Paraguayan Chaco occurred in the 1920s1930s, when eastern European and Canadian Mennonites of German descent, fleeing their countries because of religious persecution and/or war, began to settle in the region. The Mennonite communities cleared forestlands for crop and

\footnotetext{
${ }^{1}$ In Paraguay, all territory west of the Paraguay River is known as the Chaco region. Territory east of the river, despite being a part of the wet Chaco biome, is not considered part of the administrative Chaco region.
} 
pasture land, and imported pasture grass optimized for cattle grazing (buffelgrass), transforming the central Chaco region into a major cattle ranching region by the 1960 s and establishing the dominant land tenure regime seen to this day (Fehlenberg et al. 2017). Despite the extreme climate, the Mennonite colonies expanded and diversified their production to include sorghum, cotton, peanuts, cassava, and industrialized dairy production (1970s), as well as modern cattle farming using advanced genetics/breeding techniques and technologies (1980s) (Baumann et al. 2016; Neufeld 2018). The latest wave of land use dynamics in the Paraguayan Chaco began in the mid-2000s, sparked by the 2004 zero-deforestation law (Zero Deforestation Law 2004), implemented by the Paraguayan federal government in the Atlantic Forest region. This law limits forestland conversion in the Eastern portion of the country and does not apply in the Chaco region (Yanosky 2013). These new dynamics are characterized by rapid forest to pastureland conversion in the Chaco via producers moving westward from the consolidated and cleared eastern Atlantic Forest region of Paraguay looking to expand their production, foreign investors and producers, and the Chaco's Mennonite populations expanding their operations (Vázquez 2013; Zoomers and Goldfarb 2013).

\section{Soybean production in the Paraguayan Chaco}

Large-scale cropland production was long considered unfeasible in the Paraguayan Chaco due to extreme heat, flooding, droughts, salinized groundwater and soil, and lack of roads and infrastructure (Veit and Sarsfield 2017). Despite this reputation, soil types found in certain parts of the Chaco region are comprised of quickly mineralizing, fertile substrates containing high levels of organic phosphorus that are highly suitable for cropland production (Baumann et al. 2017b). Nevertheless, the harsh environmental conditions in the region created strong cultural norms that split the identity of agricultural producers in the east and west of the country- the Chaco is known as pastureland dominated by cattle producing Mennonite producers, and the east is for cropland production by Paraguayan and producers of Paraguayan/Brazilian descent known as "Brasiguayos" (Turzi 2017; Veit and Sarsfield 2017). Despite this cultural mindset, the Chaco region has seen a recent increase in cropland agriculture using no-till agriculture techniques, advanced seed technologies, and the application of glyphosate since the 2010s (Neufeld 2018). This type of expansion has been of particular interest to the Paraguayan central government, producers, agricultural industry groups, and conservation groups alike, as Eastern Paraguay has nearly reached the legal and biophysical limits of Paraguay's most important crop, soybeans (USDA-FAS 2018). Today, the Chaco holds the only major agricultural expansion potential in the country and is gaining attention as a potential economic boom area (MOPC 2019).
Environmental and human rights groups are also monitoring soybean expansion and economic development plans in the region, and monitoring for potential negative socioenvironmental impacts to indigenous groups and the environment resulting from this growth (BASE 2017; Mighty Earth 2018; WWF 2016). However, these concerns have not yet reached widespread international attention - a pattern seen in the Argentine Chaco (Kuemmerle et al. 2017) —or other biomes in South America (e.g., Brazilian Amazon and Cerrado) where conservation efforts peaked once the biome had already been strongly transformed (Strassburg et al. 2017), limiting the scope of mitigating conservation initiatives. The inherent conflict between potential economic growth and development supported by the agricultural sector and civil society's focus on nature conservation and indigenous rights are at the heart of ongoing territorial changes, all of which could escalate as soybean production takes hold in the region. In January 2018, there were over 20,000 hectares of soybean production in the Chaco region (ABC Color 2019a) - estimates for 2020 suggest that around 48,000 hectares have been planted (RCC 2020), indicating an increase of $140 \%$ in around 2 years.

\section{Methods/data}

We used a combination of field interviews and data analysis, and an extensive literature review to identify the drivers shaping the soybean frontier in the Paraguayan Chaco and to assess the soybean expansion potential in the region. We faced several constraints to data acquisition, as there is little publicly available data, and incomplete and dated information regarding agricultural census data, land prices, and infrastructure, making it difficult to assess current market values and conditions. As a result, our soybean observation data is based on information from several sources but is limited to a small number of observations from the still-nascent soybean industry in the region.

\section{Analysis of drivers and conditions of soybean expansion in the Paraguayan Chaco}

Our analysis considers the combination of external factors influenced by the underlying conditions of agricultural production and how they interact with heterogeneous actor characteristics to shape agricultural expansion dynamics in the region. As a foundation, we rely on the Von Thünen landrent framework underlying many agricultural frontier analyses (Angelsen 2010; Kellerman 1978) enriched by studies that consider power structures, incentives, and institutions. Jepson (2006), Le Polain de Waroux et al. (2018), Angelsen (2010), and Frey et al. (2018) helped inform our conceptual framework, which disaggregates elements that shape the scale and scope of agricultural frontier expansion into three 
interacting elements: (1) underlying and proximate causes; (2) spatial determinants and required conditions; and (3) individual actor characteristics (supplementary online material section 1).

We collected both qualitative and quantitative data on four field visits to Paraguay and the Chaco region, during 2018 and 2019, where we interviewed 25 key stakeholders. Twelve stakeholders were active soybean producers (5 large-scale producers, 3 medium-sized producers, 4 small-scale producers). Another 12 were technical experts working on the soy sector in the region: (7), researchers and NGO staff (5), and (1) active in a producer/trade group. Interview questions were related to when they were first aware of soybean production in the Chaco; their experiences with/around production in the Paraguayan Chaco; their opinions as to why soybean production began to expand to the Chaco region; challenges and limitations to production; and their perception of the future of soybean production in the region. Key actors were identified by attending meetings and conferences in the Chaco region related to commodity crop production, sustainability initiatives, and no-till agriculture methods. We further applied the so-called snowball method to identify further relevant stakeholders (Morgan 2008). Interviews were semi-structured, establishing pre-defined topics and questions for each actor type and open elements responding to general reactions and enthusiasm to specific topics by the interviewee (Clifford et al. 2012). We gathered additional information in public social media forums, group chats, and other informal and publicly available information exchanges used by producers in the Chaco region. Additionally, we relied on newspapers, publications, gray-literature, reports, and quantitative data found in presentations and workshops collected on our field visits to expand the scope of our analysis and gain further up-to-date context.

\section{Potential soybean area expansion}

To determine the potential future extent of soybean expansion in the Paraguayan Chaco, we systematically compared relevant biophysical and economic indicators of the coordinate points of all known soybean production in the region (supplementary online material section 1 ) with candidate locations that exhibit comparable conditions. We identified 36 locations where soybean production was observed in the Paraguayan Chaco based on field and farm visits, participation in meetings and social media groups, and recent global soy crop maps (University of Maryland/Hansen, M. C. (Unpublished): see supplementary online material section 2). With these data, we constructed a preliminary assessment of soybean suitability in the Chaco based on the location of known soy farms, referred to as presence data in the literature, with biophysical and economic variables particular to their specific coordinate points. We used soil, infrastructure, and historical land cover maps, historical bioclimatic data, and economic variables such as land price and distance to markets to create a projection of the spatial extent of soybean production using a species distribution modeling (SDM) framework (see Table 1 for a full list of variables and data sources and supplementary online material section 7-8 for a detailed description of each of the sources). This approach is similar to Frey et al. (2018), which implements the maximum entropy approach (supplementary online material section 9) to project soybean expansion in Brazil-based observed locations of soybean production. SDM was originally developed to identify niches and geographical distributions of species in Ecology and has been shown to produce reliable results in rare or narrow ranged species with as little as 3 observations and with as little as 25 observations in widely distributed species (van Proosdij et al. 2015). Studies such as de Souza and de Marco (2014), Amici et al. (2017), and Frey et al. (2018) use MaxEnt SDM modeling to predict changes in LULC based on presence data.

\section{Results}

Our analysis considers each of the previously identified elements that contribute to the formation of the modern agricultural frontier: (1) underlying and proximate drivers; (2) spatial determinants and required conditions; and (3) individual actor characteristics.

\section{Drivers of soybean expansion in the Paraguayan Chaco}

\section{Underlying and proximate drivers of soybean expansion in the Chaco}

Initially, we considered all known underlying and proximate drivers of soybean expansion (supplementary online material section 1), and then systematically ruled out any that did not apply to soybean expansion dynamics in the Paraguayan Chaco. Over two-thirds of our interviewees stressed that limitations in infrastructure and changes in demand for soybeans did not play a major direct role in driving the current wave of soybean frontier expansion. This perspective was supported by the general downtrend in soybean prices between 2012 and 2017 (World Bank Group 2017), as well as low levels of investment in infrastructure in the last decade (Veit and Sarsfield 2017). Instead, respondents listed factors related to technological changes, policy changes, and favorable land price in driving soybean expansion, described in detail below.

Technology All 25 interview respondents cited advancements in agricultural technology, specifically genetically modified seed varieties, the control of pathogens, insects, and weeds 
Table 1 Variables used in Maxent model

\begin{tabular}{|c|c|c|c|}
\hline Category & Variable & Code & Source \\
\hline Agricultural suitability & Annual mean temperature & bioclim 1 & worldclim data set [Fick et al. 2016] \\
\hline Agricultural suitability & Mean diurnal range (mean of monthly maxtemp-mintemp) & bioclim 2 & worldclim data set [Fick et al. 2016] \\
\hline Agricultural suitability & Isothermality & bioclim 3 & worldclim data set [Fick et al. 2016] \\
\hline Agricultural suitability & Temperature seasonality & bioclim 4 & worldclim data set [Fick et al. 2016] \\
\hline Agricultural suitability & Max temperature of warmest month & bioclim 5 & worldclim data set [Fick et al. 2016] \\
\hline Agricultural suitability & Min temperature of coldest month & bioclim 6 & worldclim data set [Fick et al. 2016] \\
\hline Agricultural suitability & Temperature annual range & bioclim 7 & worldclim data set [Fick et al. 2016] \\
\hline Agricultural suitability & Mean temperature of wettest quarter & bioclim 8 & worldclim data set [Fick et al. 2016] \\
\hline Agricultural suitability & Mean temperature of driest quarter & bioclim 9 & worldclim data set [Fick et al. 2016] \\
\hline Agricultural suitability & Mean temperature of warmest quarter & bioclim 10 & worldclim data set [Fick et al. 2016] \\
\hline Agricultural suitability & Mean temperature of coldest quarter & bioclim 11 & worldclim data set [Fick et al. 2016] \\
\hline Agricultural suitability & Annual precipitation & bioclim 12 & worldclim data set [Fick et al. 2016] \\
\hline Agricultural suitability & Precipitation of wettest month & bioclim 13 & worldclim data set [Fick et al. 2016] \\
\hline Agricultural suitability & Precipitation of driest month & bioclim 14 & worldclim data set [Fick et al. 2016] \\
\hline Agricultural suitability & Precipitation seasonality (coefficient of variation) & bioclim 15 & worldclim data set [Fick et al. 2016] \\
\hline Agricultural suitability & Precipitation of wettest quarter & bioclim 16 & worldclim data set [Fick et al. 2016] \\
\hline Agricultural suitability & Precipitation of driest quarter & bioclim 17 & worldclim data set [Fick et al. 2016] \\
\hline Agricultural suitability & Precipitation of warmest quarter & bioclim 18 & worldclim data set [Fick et al. 2016] \\
\hline Agricultural suitability & Precipitation of coldest quarter & bioclim 19 & worldclim data set [Fick et al. 2016] \\
\hline Agricultural suitability & Soil type & soil & Guyra 2012 \\
\hline Accessibility & Distance to city & dist_cites & $\begin{array}{l}\text { Authors' own calculation based } \\
\text { on (Schielein et al. 2021) }\end{array}$ \\
\hline Accessibility & Distance to port & dist_ports & $\begin{array}{l}\text { Authors' own calculation based } \\
\text { on (Schielein et al. 2021) }\end{array}$ \\
\hline Land price & Land price & land_price & UGP/MF 2017, MAG 2016 \\
\hline Land use & $\begin{array}{l}\text { Land cover (separated into } 9 \text { types highlighted in } \\
\text { supplementary online material section } 7 \text { ) }\end{array}$ & land_use & WWF/Guyra/DLR 2016 \\
\hline Land use & Protected area & protected_area & WWF 2016 \\
\hline
\end{tabular}

through chemical inputs in combination with no-till planting techniques as the major proximate driver contributing to soybean expansion in the Paraguayan Chaco. We found that of these technologies, the ubiquitous use of no-till planting on top of flattened cover crops as a moisture retention technique is considered by all interviewed respondents as having played the largest role in facilitating soybean expansion, by mitigating the impacts of drought and high heat (RCC 2020). No-till methods were first implemented on a large scale in the Paraguayan Chaco via replication of experiences with soybean production in the Salta and Chaco provinces in Argentina (Fehlenberg et al. 2017; Zoomers and Goldfarb 2013) (interviews 1, 3, 4- see supplementary online material). Complimentary to this change in technology in the region, but often cited as the technological factor that will unlock the region for further soybean expansion, is the development and use of drought-resistant genetically modified (GM) seed technologies and glyphosate application (USDA-FAS 2018). As of 2019, over 340 soybean varieties had been tested in the Paraguayan Chaco with the most success seen in seed maturity groups with longer maturation periods (Dueck 2018). These dynamics will continue to play a role as production methods and seed genetics improve and are further specialized to conditions present in the region.

Policies and governance The 2004 zero-deforestation law (Zero Deforestation Law 2004) in the eastern region of the country spurred a new wave of investment in the Chaco, as it the only region in Paraguay where forest to pasture/cropland conversion remains legal. Seven of the interview respondents cited the implementation of this law as an underlying dynamic driving soybean expansion in the Paraguayan Chaco, in addition to the relatively few restrictions placed on agricultural producers operating in the region. In order to be compliant with federal environmental laws, rural properties in the Chaco need to maintain a legal reserve of natural forests 
totaling at least 25\% (Forest Reserve Law 422/73, Decree regulation 18831/86 1973) of their property size, in addition to maintaining the "preservation and management of watersheds and wetlands" (National System of Wild Protected Areas of Paraguay Act (SINASIP) 1994), as well as the obligation to perform environmental impact studies. Additionally, few ownership restrictions for foreign land owners (except for a $50 \mathrm{~km}$ buffer from national borders), low tax rates, and poor enforcement of regulations by the federal government are further conditions that are favorable to agricultural expansion by both domestic and international actors operating in the region, including soybean producers (IUCN 2019; Redo et al. 2011; Veit and Sarsfield 2017).

Land price In 2008, an average hectare of forestland in the Chaco was valued at roughly USD $\$ 40-50$, rising to USD \$250-300 in 2012 (Galeano 2012). Today, forested land can sell for USD\$150-600 per hectare, and cleared pastureland can sell for USD\$500-2000 per hectare (Veit and Sarsfield 2017). Despite these increases, Paraguayan land ranks among the lowest land valuations in Latin America, second only to Bolivia, attracting producers looking to expand their pasture/croplands as well as international actors looking to invest in land deals with an expected high return on investment (Veit and Sarsfield 2017). Seventeen of our respondents cited "consistently appreciating land prices" as being a major underlying driver of soybean frontier expansion. As more actors began to purchase land in the Chaco region, land prices increased, attracting domestic and increasingly foreign investors operating in cattle production, land speculation, and eventually soybean production from Argentina, Brazil, Uruguay, and further abroad (Veit and Sarsfield 2017).

\section{Spatial determinants and required conditions for agricultural production}

Our study identified three contributing determinants and conditions for soybean production: soil highly suitable for agricultural production, perceived increases in precipitation, and adequate levels of infrastructure (supplementary online material section 1 ).

Suitability for agricultural production If producers can mitigate challenges attributed to water scarcity and can access zones with suitable soil types, the Paraguayan Chaco is biophysically apt to modern soybean production technology. This is supported by all interview respondents who indicated the high soil fertility in the region favors suitability for agricultural production. High soil fertility can reduce input costs for soybean production by reducing the need for fertilizer at a savings of roughly $30 \%$ compared to other regions in Paraguay, potentially offsetting significant transportation costs of bringing soybeans to market (interview 1, 5, 7- see supplementary online material).

Throughout our interviews, the majority of respondents cited increased levels of precipitation to be a potential factor driving soybean frontier expansion in the Chaco, as water scarcity is the greatest limiting factor in agricultural production in the region. Recent studies have suggested a potential increase in precipitation and extreme weather events in Northern Argentina, and several other surrounding regions (Barros et al. 2008; Ferrero and Villalba 2019). However, according to historical climate data based on the 2017 CRU Dataset (Harris et al. 2020), we did not find a significant variation in precipitation or temperature between the years 1980 and 2016 in various locations throughout the Paraguayan Chaco in the months surrounding soybean production and harvest which occur between November and April (supplementary online material section $3 \mathrm{a}-\mathrm{b}$ ). To understand the discrepancy between our climate assessment and the reported increase in precipitation by many interviewees, we undertook an exhaustive literature review of studies focused on the Gran Chaco region and the entire La Plata Basin. Our review considered studies that claim overall increasing precipitation across the La Plata basin such as Grimm et al. (2016) that looks at overall precipitation trends in the region between 1970 and 2005, as well as studies from neighboring regions (Mato Grosso do Sul, Brazil) reporting stable precipitation patterns between 1954 and 2013 (Teodoro et al. 2016). Additionally, we examined studies focused on the relationship between land use, atmospheric moisture recycling, and precipitation patterns in the region (Keys et al. 2016), the impacts of climate change on El Niño and La Niña weather events in South America (Cai et al. 2015; Pezzoli and Ponte 2016), as well as studies pertaining to water resources specific to Paraguay (Coronel et al. 2015). Despite this line of inquiry, we did not find any empirical evidence specific to changing precipitation levels or temperatures and soybean expansion in the Paraguayan Chaco. This assessment is in line with dynamics observed in the Northern Argentine Dry Chaco region, whereby rainfall was ruled out to be a major determinant of cultivated land expansion (Gasparri et al. 2015).

These findings do not eliminate the possibility of localized increases in precipitation in recent years that are not covered by the available data. Nor does it eliminate the possibility that perceived increases in precipitation by producers may have occurred as a result of prevailing opinions in the region and/or the success of recently implemented moisture conserving production methods. Either of these outcomes could influence the decision-making and risk assessments of producers as to whether they engage in soybean production. However, similar to Gasparri et al. (2015) in the Argentine Chaco, we have ruled out recent increases to precipitation as a major determinant in soybean expansion in the Paraguayan Chaco. 
Infrastructure The lack of reliable infrastructure in the Chaco region is a challenge for all actors engaged in economic activities in the region. To date, the trans-Chaco highway is the only non-urban paved road facilitating agricultural production and transportation in the region (Fig. 1). At present, harvested soybeans bound for export originating in the Paraguayan Chaco travel considerable distances to reach grain ports in Concepción (roughly $350 \mathrm{~km}$ ) and, more frequently, the Asuncion/Villeta area (roughly $450 \mathrm{~km}$ ), and can only be transported in dry conditions, as unpaved roads become impassible if wet. Despite these difficulties, current levels of accessibility and infrastructure have been sufficient to meet the minimum requirements of satisfying the required conditions for agricultural supply chains if goods are transported during dry periods, despite reported difficulties and lost or damaged harvests due to wet conditions (interview 1 - see supplementary online material). Despite its current marginal role in driving soybean expansion dynamics, improvements in accessibility could become one of the most important drivers of frontier expansion in the region, as it is one of the most frequently cited drivers of both pastureland and cropland expansion in the greater Gran Chaco (Le Polain de Waroux et al.

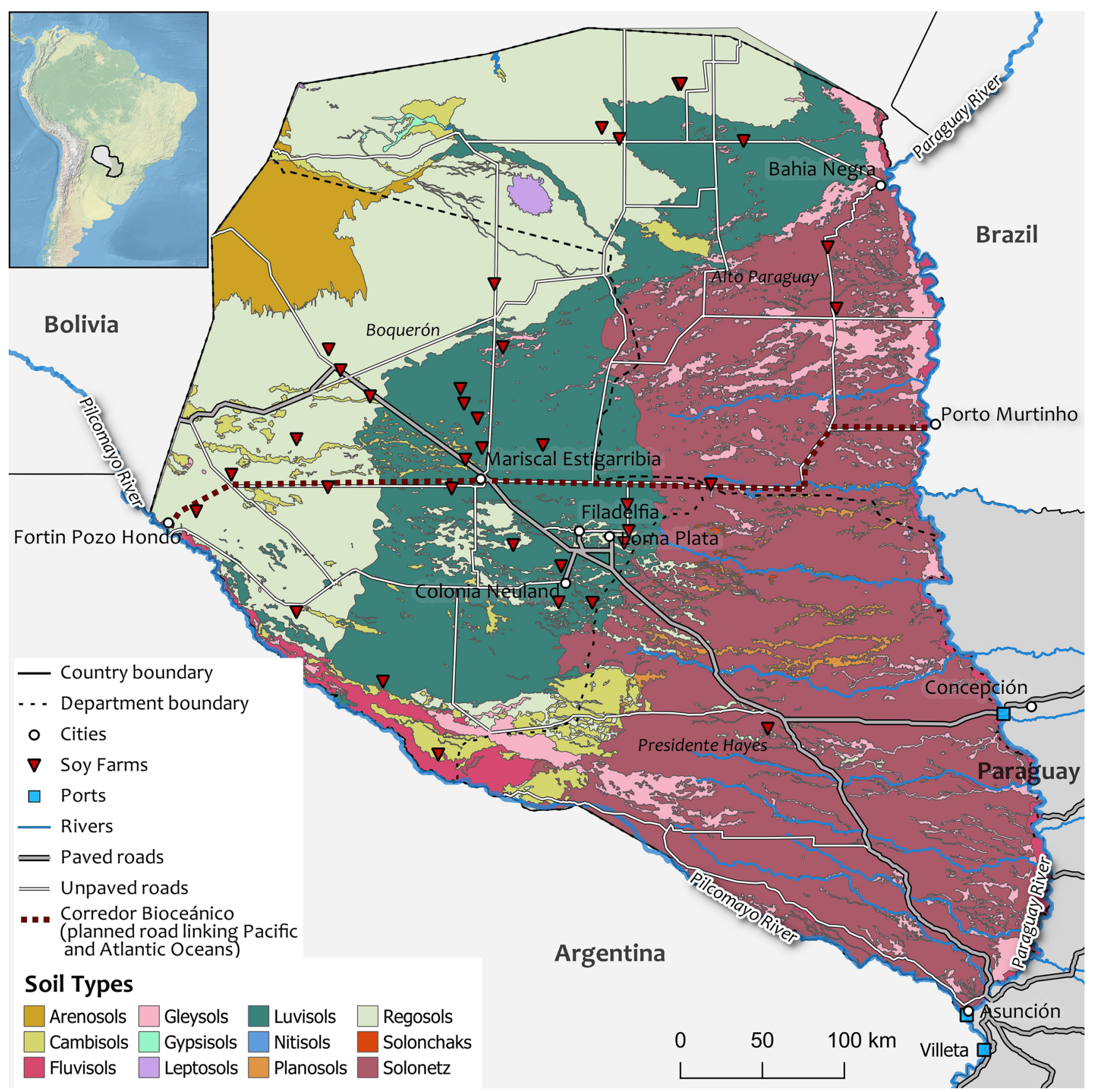

Fig. 1 Observed soybean presence according to soil types in the Paraguayan Chaco 
2016; Piquer-Rodríguez et al. 2018; Volante et al. 2016). Increased accessibility could make soybean production viable in regions that are currently inaccessible, sparking a change in the underlying profitability of cropland production in the region through scaling and agglomeration effects (Le Polain de Waroux et al. 2018).

\section{Actor characteristics}

The decision parameters and behaviors of different actor types play a role in soybean expansion dynamics in the Paraguayan Chaco. This understudied element of agricultural frontier expansion dynamics is explained in detail below.

Access to information Access and availability to information for decision-making is strongly linked to actor type in the Paraguayan Chaco. For instance, all interviewed large-scale soybean producers (supplementary online material section 4) have adopted technologies and production schemes from other soybean-producing regions due to personal experience or first-hand gathered information about best practices in those regions. The majority of interviewed medium to smaller sized producers expressed that they lack the resources to be able to gain access to this type of information due to the prohibitive cost of attending meetings or a lack of awareness that this type of information is being shared without outside assistance or the selective transfer of information by larger producers. Large-scale soybean producers are highly engaged in disseminating information and actively contribute to workshops and events organized by civil society and the government ${ }^{2}$, in addition to personal networks, agricultural expos, and public and private social media groups. Large-scale actors can leverage their influence to control the flow of information between in-groups that share information, and out-groups that are not privy to information, through invitations to meetings and/or social media groups similar to observations described in (Le Polain de Waroux et al. 2018).

Preferences Komarek et al. (2020) outlines a large body of literature about how producers position themselves and make decisions based on intrinsic levels of risk tolerance and how this defines individual preferences. We analyzed actor preferences in the Paraguayan soybean frontier in the Chaco and concluded that producers' level of risk tolerance varies greatly depending on their size, incentives, and identity, and affects the type of frontier expansion they engage in. The largest producers active in soybean production in the Paraguayan Chaco focus on producing soybeans for export, as a short to

\footnotetext{
${ }^{2}$ Including the Green Commodities/Green Chaco project (United Nations Development Programme UNDP) and the Paraguayan Department of Environment and Sustainable Development (MADES) and Promesa Chaco (Guyra/MADES)
}

mid-term return on investment, and are active in direct forest clearing to soybean production (interview 1 - see supplementary online material). The long-term focus of these producers is to develop forestland properties into cropland and pastures, increase their property values, and sell them as land prices appreciate ${ }^{3,4}$. Their risk preferences are, therefore, inherently less conservative than among small/medium scale producers looking to diversify their economic activities or supplement their cattle operations through soybean production, which is more likely to occur on previously cleared land due to the high costs of land transformation (Neufeld 2018). Therefore, how soybean expansion occurs in the Chaco is different between actor types based on risk tolerance and subsequent preferences. Preferences can also lead actors to respond to nonrent based incentives, acquiring land to demonstrate prestige or status, the building of in and out-groups, or maintaining a "pioneer identity" observed in the Turner frontier thesis (Foa et al. 2012; Turner 1920) all of which do not lend themselves to quantification (Turner 1920). If the utility from engaging in frontier expansion offsets the conventional von Thünen logic of rents decreasing with distance to markets, a small number of risk-taking producers may act as the early innovators needed to catalyze large-scale landscape transformation. Our interviews suggest that soybean frontier expansion in the Paraguayan Chaco is co-determined by the particular risk attitudes that dominate among pioneering large-scale producers in the region. As one large-scale producer stated "soybeans are coming to the Chaco ... people used to think that I was crazy for thinking it could become a soybean production region, but now it's me producing the soybeans" (interview 1 - see supplementary online material).

Agency Individual actors' ability to influence their rent conditions in the future reflects their level of agency and is largely dependent on their ability to organize and lobby (Jepson 2006; Le Polain de Waroux et al. 2018). In the Paraguayan Chaco, examples of differential levels of agency between actors can range from lobbying the central government for investments in infrastructure, to building roads, and providing input to planned changes in regulations (ABC Color 2019c), to organizing aid during extreme weather events or natural disasters (ABC Color 2019b). Mennonite producers have achieved high levels of agency through the governance structures of their respective colonies and the resources they control and administer. They have built private roads, facilitated land deals, purchased state-of-the-art machinery, and installed private agricultural extension and research programs for their members based on high levels of the organization. Several colonies are currently participating in research and development programs to improve soybean genetics for improved

\footnotetext{
$\overline{3}$ http://www.cresud.com.ar/campania-nuestro-negocio.php?language=en,

${ }^{4} \mathrm{http}: / /$ www.carloscasadosa.com/tierras.php
} 
drought tolerance in collaboration with the Paraguayan Grains and Oilseeds Traders Association (CAPECO), the US Department of Agriculture (USDA), and the University of Missouri (La Nación 2017). The large-scale soybean producers in the Chaco (supplementary online material section 4) also exhibit high levels of agency in shaping the Chaco soybean frontier by influencing policy, lobbying for increased infrastructure spending, private non-state sponsored road building (Veit and Sarsfield 2017), and shaping the flows of information and discourse related to development in the region by forming alliances with projects sponsored by international organizations ${ }^{5}$. These actors speak at events and independently organize soybean producers active in the Chaco at all scales through meetings, events, and social media groups.

Access to land and capital The differences in resources between actors and their comparative advantages dictate their relative access to an agricultural frontier zone. In a non-state driven frontier region, differential access to capital, credit, land, technical expertise, and trade networks impact whether an actor can expand to a region that may be "inaccessible" to other producers due to a lack of available resources (Le Polain de Waroux et al. 2018). In the Paraguayan Chaco soybean frontier, different actor categories bring different levels of access due to their respective level of capitalization, cultural affiliation, level of education, or if they represent a larger company or producer. Two of the three largest companies (Moroti \& Palmeiras S.A, Carlos Casado) represent international agricultural interests, and can expand to regions that would be inaccessible to smaller producers due to constraints in credit and capital required for forest to cropland conversion (interview 1 - see supplementary online material). Actors affiliated with the Mennonite colonies are able to access land for soybean expansion that is not available to non-members due to private ownership based on membership to the colonies (interview 13-see supplementary online material). Access thus plays a key role in determining the extent to which soybean expansion can or cannot take place in the Paraguayan Chaco.

\section{Potential for soybean expansion in the Paraguayan Chaco}

As of 2019, we identified 36 different instances of soybean production occurring in the Paraguayan Chaco (Fig. 1). Due to data limitations, the novelty of soybean production in the region, and time constraints, we cannot determine if these

\footnotetext{
${ }^{5}$ Including projects sponsored by the United Nations such as Project Green Chaco: https://www.py.undp.org/content/paraguay/es/home/projects/ greenchaco.html; and FOLUR: https://www.thegef.org/sites/default/files/ web-documents/10397_add_PFD_child_projects.pdf
}

observed production areas are an exhaustive list, nor could we field verify each location. However, the points included in the analysis were cross-referenced with other data sources/ interviews when possible and represent the most comprehensive list of soybean production locations in the Paraguayan Chaco to date.

The agricultural suitability requirements for soybean production are highly dependent on the previous land use/land cover and biophysical characteristics of production areas such as soil type, precipitation, and temperature. The most static of these variables is soil type, as it is more consistent on a yearto-year basis and whose characteristics play the most significant role in determining the spatial extent of soybean production. The Paraguayan Chaco consists of 12 soil types, of which three make up the vast majority of the territory: Solonetz (34 at.8\%), Regosols (27.6\%), and Luvisols (20.4\%). The majority present-day soybean production in the Paraguayan Chaco occurs in Regosols and Luvisols (86.1\%), followed by Solonetz $(11.1 \%)$ and Cambisols $(2.7 \%)$ (supplementary online material section 5).

According to our field observations, soybean production in the Chaco has occurred, by in large, on previously cleared pastureland, except in the cases where forestland was transformed to soybean production as a part of large-scale land development (Passerieu 2018). A map of soybean presence according to historical land use can be found in supplementary online material section 6. A preliminary assessment of how much land is apt for soybean expansion based solely on soils and land use/cover consists of previously cleared pastureland subsisting of Luvisol and Regosol soil, which adds up to a total of 2.9 Mha across the Paraguayan Chaco (roughly the size of Belgium). This assessment does not take continued pasture use and cropland/pasture competition into account, nor does it include additional socioenvironmental variables such as precipitation, temperature, distance to port, land price, and infrastructure. To establish a more detailed exploratory projection of soybean apt production regions in the Chaco that considers additional available data, we implemented the Maxent SDM model (supplementary online material section 9).

We estimate that roughly 742,000 hectares in the Chaco, roughly $3 \%$ of the territory, are high or very highly apt for soybean production (Fig. 2). If we project an average yield of 2.9 Tn/ha (similar to the Argentinean Chaco), this expansion has the potential to contribute an additional $2.15 \mathrm{Mtn}$ more to Paraguay's current soy production (9.8 Mtn), an increased output of roughly $22 \%$. The department with the largest projected soybean expansion potential is Boquerón, where the majority of "high and very high soybean occurrence probability," occur. We identified an additional 940,000 hectares, roughly $4 \%$ of the territory, as moderately apt for soybean expansion, concentrated in Central and South Western Boquerón, with additional presence in the Agua Dulce region of Alto Paraguay. 


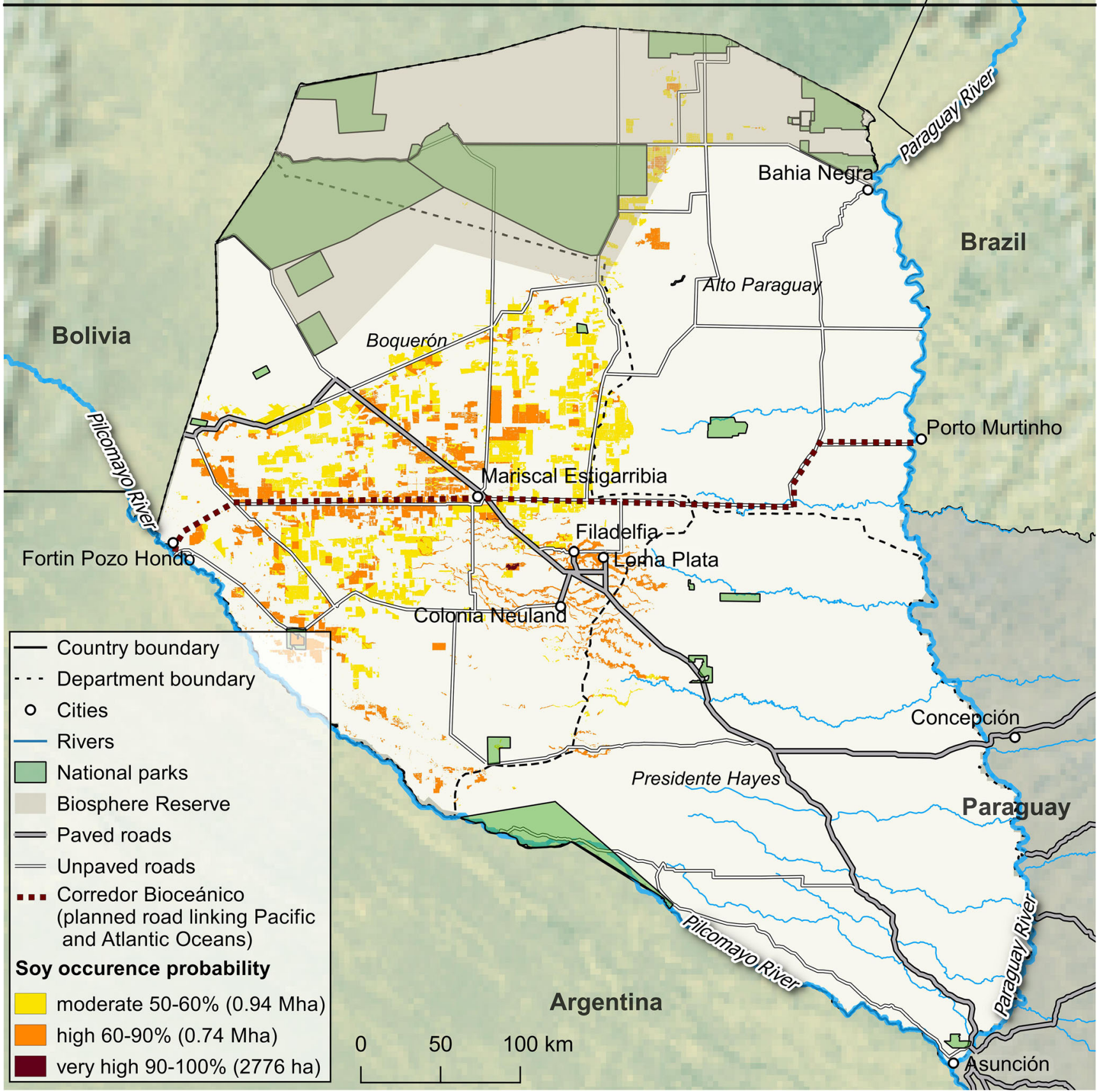

Fig. 2 MaxEnt Projection of total potential soybean expansion in the Paraguayan Chaco

According to our model, the variable with the highest explanatory power when used in isolation is land cover (labeled "land use" in supplementary online material section 11). The land cover variable also changes the model outcome the most when it is omitted, suggesting that it contains the highest level of non-redundant information in the available set of covariates. The relative importance of the land cover variable is supported by information gathered by our field visits, as the vast majority of observed soybean production recorded in our study occurs on previously cleared pasture. The next two significant variables are soil type and the maximum temperature in the warmest month (Table 1). These findings were also supported by our field visits and the preliminary suitability assessment based on soil types as they play an important role in where soybean production has been observed and reflects the consensus of all interviewed stakeholders about the difficulty of agricultural production in extreme heat and drought conditions. We note that this projection uses limited data on a highly dynamic and nascent agricultural frontier and is intended to serve as an exploratory assessment of the potential for large-scale soybean production in the Paraguayan Chaco. 


\section{Discussion}

This study provides a unique early snapshot of the drivers of soybean expansion in the Paraguayan Chaco and is the first to project potential frontier expansion dynamics in the region. We find that the most important proximate driver behind recent soybean frontier expansion in the Paraguayan Chaco was an advance in agricultural technology, particularly no-till agriculture production methods, consistent with findings found in (Turzi 2017; Zoomers and Goldfarb 2013) that suggest that the potential area for global soybean production is based on increased agronomic and economic viability across the continent gained by advances in technology. The most important underlying causes of soybean expansion in the Paraguayan Chaco were a combination of the region's fertile soils, consistent appreciation of land prices, favorable regulations, and a sufficient level of precipitation and infrastructure. These findings are similar to dynamics seen in the Argentine Chaco in previous decades (Piquer-Rodríguez et al. 2018; Zoomers and Goldfarb 2013), but some localized peculiarities apply. The Paraguayan Chaco, despite its proximity and climatic similarities to the Argentine Chaco, has only recently emerged as a soybean expansion region due to the changing preferences of actors spurred by foreign land development companies looking to develop properties for speculation, Mennonite affiliated producers looking to diversify their production, and a deforestation ban in the eastern region of the country limiting forest to soybean expansion to the Western (Chaco) half of the country. The time lag between soybean frontier expansion in the Argentine Chaco and the Paraguayan Chaco demonstrates the important role that actor types play in driving frontier dynamics in each respective region. The comparative advantages of individual actors engaged in soybean expansion in the Paraguayan Chaco differ from their Argentine or Amazonian counterparts (Le Polain de Waroux et al. 2018).

We project that roughly 742,000 hectares in the Chaco are highly or very highly suitable for soybean frontier expansion based on current production observations and 2018 levels of infrastructure, with an additional 940,000 hectares projected to be moderately suitable for soybean expansion, totaling 1.68 Mha, potentially producing up to 2.15 Mtn of soybeans. However, these estimates could shift and increase significantly with improvements to infrastructure, given that the low levels of infrastructure have not hampered the incipient but rapid soy expansion, unlike in other soy expansion regions such as the Brazilian Amazon and Cerrado (Garrett et al. 2013) or the Argentine Chaco (Zoomers and Goldfarb 2013). Our interviews and projections support the narrative that attributes the high deforestation rates in the Paraguayan Chaco the last decade mostly to cattle production (Baumann et al. 2017b; Caldas et al. 2015). However, beyond this fairly well understood dynamic, we indicate, based on our projections, that further deforestation is bound to occur in the
Paraguayan Chaco both as a direct consequence of soybean expansion and through intra-regional indirect land use change (e.g., forest to pasture) as opposed to only indirect leakage effects from neighboring regions (Meyfroidt et al. 2020).

The Paraguayan Chaco is currently the only area with a high proportion of natural vegetation separating the soybean production areas of four major South American soybean production countries (supplementary online material section 2) and has acted as a de-facto barrier between the regions. This region is also the home to many indigenous communities, is the habitat to many endemic flora and fauna, and provides important ecosystem services such as carbon storage and flood regulation (Baumann et al. 2017a; Veit and Sarsfield 2017). Efforts to curb deforestation and agricultural expansion, such as the establishment of the Chaco Biosphere Reserve $^{6}$ with additional requirements for maintaining forestland have been made, but exist as a government resolution and are not part of national law, and are only partially enforced by MADES as part of the environmental impact statements needed to gain environmental licenses for clearing forestland (interview 25-see supplementary online material). Our study shows that soybean production has been observed and is projected to expand in the biosphere region and beyond (Fig. 2).

If the Chaco develops into a major soybean expansion region because of changing production dynamics, technologies, and increased accessibility, its strategic location bears the potential to regionally integrate neighboring regions and become a continental agro-industrial staging area for international exports, leading to increased capacity and intermodality of soy transportation across central South America. This development scenario would intensify the processes that have contributed to current high levels of deforestation in the Argentine Chaco (Piquer-Rodríguez et al. 2018) and the greater Chaco region (Baumann et al. 2017b), in addition to losses to ecosystem services and habitats resulting from agricultural expansion (Barral et al. 2020) and new infrastructure development (Reymondin et al. 2013).

In August 2019, the Paraguayan central government announced massive infrastructure investments in the region ( $\mathrm{La}$ Nación 2019; MOPC 2019; Paraguayan Ministry of Public Works and Communications 2020). These improvements include re-paving aging portions of the trans-Chaco highway, a new port connecting the region to the Paraguay River, improvements to the Paraguay river's navigability further connecting the region to the La Plata and Parana rivers, and a bridge connecting Paraguay to Brazil in Carmelo Peraltathe third in the country (MOPC 2019). This bridge is part of a larger 2.5 billion USD bi-oceanic corridor project "Corredor

\footnotetext{
${ }^{6}$ http://odd.senado.gov.py/archivos/file/Reserva\%20Bioferas\%20del\% 20Chaco\%20Con\%20Antec.pdf
} 
Bioceánico" funded in part by the Paraguayan and Brazilian government that, upon completion, connects South America's largest soybean-producing regions in Brazil, Paraguay, Argentina, and Bolivia ${ }^{7}$ with the Pacific Ocean, via a highway that crosses the heart of the Paraguayan Chaco (Fig. 1). The expected high levels of accessibility resulting in these infrastructure investments would reinforce the effect of development on agricultural productivity in the region by altering its underlying profitability by lowering production costs, spurring agglomeration effects and leading to economies of scale as seen elsewhere in South America (Pfaff et al. 2007; Reymondin et al. 2013). This could promote cropland production on more marginal regions in the Chaco, contributing to potentially higher levels of LULC than projected in our assessment. Understanding these dynamics before this integration occurs could potentially mitigate unintended socioenvironmental consequences of soybean expansion and regional integration.

\section{Conclusions}

This paper calls attention to the fact that current agricultural expansion dynamics in the Paraguayan Chaco resemble the early stages of large-scale soybean expansion in ecologically sensitive regions, such as the Brazilian Amazon, the Brazilian Cerrado, and Argentinean Chaco. Proactive regional land use planning is necessary to avoid the negative socio-environmental consequences of largescale land cover change in these former agricultural frontiers. The added pressure from an estimated 1.68 Mha of potential soybean expansion on the natural resources in the region could exacerbate already high levels of deforestation through both direct and indirect land use change, causing irreversible socio-environmental consequences to one of the largest remaining eco-regions in South America. Current land use regulations were enacted under the now obsolete assumption of limited development potential in the region and require revision to account for the large-scale potential for soy expansion in the biome. A forward-thinking land governance approach for the region must anticipate the completion of the planned large-scale infrastructure projects currently underway and will be critical in tempering the negative consequences of the next agricultural frontier boom in Paraguay.

Supplementary Information The online version contains supplementary material available at https://doi.org/10.1007/s10113-021-01804-z.

Acknowledgments $\mathrm{JH}, \mathrm{JG}$, and TB acknowledge the support from the Gordon and Betty Moore Foundation through the Trase project (www. trase.earth) and the Swedish Research Council "Formas" through the

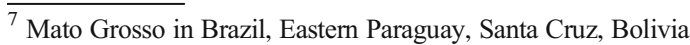

project LEAKAGE (grant number 2016-00351). JH and JB further acknowledge support from the German Federal Ministry of Education and Research (BMBF) as part of the project STRIVE (Sustainable Trade and Innovation Transfer in the Bioeconomy). This research was partially funded by the German Research Foundation under Germany's Excellence Strategy, EXC-2070 - 390732324 —PhenoRob.

Funding Open Access funding enabled and organized by Projekt DEAL.

\section{Declarations}

Conflict of interest The authors declare no competing interests.

Open Access This article is licensed under a Creative Commons Attribution 4.0 International License, which permits use, sharing, adaptation, distribution and reproduction in any medium or format, as long as you give appropriate credit to the original author(s) and the source, provide a link to the Creative Commons licence, and indicate if changes were made. The images or other third party material in this article are included in the article's Creative Commons licence, unless indicated otherwise in a credit line to the material. If material is not included in the article's Creative Commons licence and your intended use is not permitted by statutory regulation or exceeds the permitted use, you will need to obtain permission directly from the copyright holder. To view a copy of this licence, visit http://creativecommons.org/licenses/by/4.0/.

\section{References}

ABC Color (2019a) Efectos de siembra de la soja en la carne. https:// www.abc.com.py/edicion-impresa/economia/efectos-de-siembrade-la-soja-en-la-carne-1765450.html. Accessed 19 June 2020

ABC Color (2019b) Hoy podría volver a empeorar situación. https:// www.abc.com.py/edicion-impresa/locales/2019/09/15/hoy-podriavolver-a-empeorar-situacion/. Accessed 17 Nov 2019

ABC Color (2019c) Payo reflota su "deforestación cero". https://www. abc.com.py/edicion-impresa/politica/payo-reflota-su-deforestacioncero-1825790.html?desktop=true. Accessed 13 Feb 2020

ABC Color (2020) Buenos rindes compensan el menor precio de la soja. https://www.abc.com.py/edicion-impresa/economia/2020/02/19/ buenos-rindes-compensan-el-menor-precio-de-la-soja/. Accessed 21 Apr 2020

Amici V, Marcantonio M, La Porta N, Rocchini D (2017) A multitemporal approach in MaxEnt modelling: a new frontier for land use/land cover change detection. Ecological Informatics 40:40-49. https://doi.org/10.1016/j.ecoinf.2017.04.005

Angelsen A (2010) Policies for reduced deforestation and their impact on agricultural production. Proc Natl Acad Sci U S A 107:1963919644. https://doi.org/10.1073/pnas.0912014107

Barral MP, Villarino S, Levers C, Baumann M, Kuemmerle T, Mastrangelo M (2020) Widespread and major losses in multiple ecosystem services as a result of agricultural expansion in the Argentine Chaco. J. Appl. Ecol. 57:2485-2498. https://doi.org/10. 1111/1365-2664.13740

Barros VR, Doyle ME, Camilloni IA (2008) Precipitation trends in southeastern South America: relationship with ENSO phases and with low-level circulation. Theor Appl Climatol 93:19-33. https://doi. org/10.1007/s00704-007-0329-x

Baumann M, Piquer-Rodríguez M, Fehlenberg V, Gavier Pizarro G, Kuemmerle T (2016) Land-use competition in the South American Chaco. In: Niewöhner J, Bruns A, Hostert P, Krueger T, Nielsen JØ, Haberl H, Lauk C, Lutz J, Müller D (eds) Land use competition, vol 69. Springer International Publishing, Cham, pp 215-229 
Baumann M, Gasparri I, Piquer-Rodríguez M, Gavier Pizarro G, Griffiths $P$ et al. (2017a) Carbon emissions from agricultural expansion and intensification in the Chaco. Glob Chang Biol 23:1902-1916. https://doi.org/10.1111/gcb.13521

Baumann M, Israel C, Piquer-Rodríguez M, Gavier-Pizarro G, Volante JN, Kuemmerle T (2017b) Deforestation and cattle expansion in the Paraguayan Chaco 1987-2012. Reg Environ Change 17:11791191. https://doi.org/10.1007/s10113-017-1109-5

Cai W, Wang G, Santoso A, McPhaden MJ, Wu L, et al. (2015) Increased frequency of extreme La Niña events under greenhouse warming. Nature Climate Change 5:132 EP -. https://doi.org/10.1038/ nclimate2492

Caldas MM, Goodin D, Sherwood S, Campos Krauer JM, Wisely SM (2015) Land-cover change in the Paraguayan Chaco: 2000-2011. Journal of Land Use Science 10:1-18. https://doi.org/10.1080/ 1747423X.2013.807314

Clifford N, French S, Valentine G (eds) (2012) Key methods in geography, 2nd edn. Calif, Sage, Los Angeles

Coronel G, Pastén M, Báez J, Domecq RM, Bidegain M, Nagy GJ (2015) Improving capacities and communication on climate threats for water resources adaptation in Paraguay. In: Leal Filho W (ed) Handbook of Climate Change Adaptation, Springer, vol 100. Berlin Heidelberg, Berlin, Heidelberg, pp 1091-1108

de Souza RA, de Marco P (2014) The use of species distribution models to predict the spatial distribution of deforestation in the western Brazilian Amazon. Ecological Modelling 291:250-259. https://doi. org/10.1016/j.ecolmodel.2014.07.007

Dueck J (2018) Resultados de Soja en Chortitzer. Green Commodities / Plataforma Regional de Carne Sostenible, Filadelfia, Paraguay

Eufemia L, Bonatti M, Sieber S, Schröter B, Lana MA (2020) Mechanisms of weak governance in grasslands and wetlands of South America. Sustainability 12:7214. https://doi.org/10.3390/ su12177214

Fehlenberg V, Baumann M, Gasparri NI, Piquer-Rodriguez M, GavierPizarro G, Kuemmerle T (2017) The role of soybean production as an underlying driver of deforestation in the South American Chaco. Global Environmental Change 45:24-34. https://doi.org/10.1016/j. gloenvcha.2017.05.001

Ferrero ME, Villalba R (2019) Interannual and long-term precipitation variability along the subtropical mountains and Adjacent Chaco (22-29 ${ }^{\circ}$ S) in Argentina. Front. Earth Sci. 7:505. https://doi.org/ $10.3389 /$ feart. 2019.00148

Foa R, Nemirovskaya A, Mostovova E (2012) Internal empires I: social institutions of the frontier. SSRN Journal. https://doi.org/10.2139/ ssrn. 2073331

Forest Reserve Law 422/73 (1973) Decree regulation 18831/86: Law $422 / 73$

Frey G, West T, Hickler T, Rausch L, Gibbs H, Börner J (2018) Simulated impacts of soy and infrastructure expansion in the Brazilian amazon: a maximum entropy approach. Forests 9:600. https://doi.org/10.3390/f9100600

Galeano LA (2012) Paraguay and the expansion of Brazilian and Argentinian agribusiness frontiers. Canadian Journal of Development Studies/Revue canadienne d'études du développement 33:458-470. https://doi.org/10.1080/02255189. 2012.744301

Garrett RD, Lambin EF, Naylor RL (2013) The new economic geography of land use change: supply chain configurations and land use in the Brazilian Amazon. Land Use Policy 34:265-275. https://doi.org/10. 1016/j.landusepol.2013.03.011

Gasparri NI, Grau HR, Sacchi LV (2015) Determinants of the spatial distribution of cultivated land in the North Argentine Dry Chaco in a multi-decadal study. Journal of Arid Environments 123:3139. https://doi.org/10.1016/j.jaridenv.2015.05.005

Gasparri NI, Kuemmerle T, Meyfroidt P, Le Polain de Waroux Y, Kreft H (2016) The emerging soybean production frontier in Southern
Africa: conservation challenges and the role of south-south telecouplings. Conservation Letters 9:21-31. https://doi.org/10. $1111 /$ conl.12173

Godar J, Gardner TA, Tizado EJ, Pacheco P (2014) Actor-specific contributions to the deforestation slowdown in the Brazilian Amazon. Proc Natl Acad Sci U S A 111:15591-15596. https://doi.org/10. 1073/pnas.1322825111

Hansen MC, Potapov PV, Moore R, Hancher M, Turubanova SA et al. (2013) High-resolution global maps of 21st-century forest cover change. Science 342:850-853. https://doi.org/10.1126/science. 1244693

Jepson W (2006) Producing a modern agricultural frontier: firms and cooperatives in eastern Mato Grosso, Brazil. Economic Geography 82:289-316. https://doi.org/10.1111/j.1944-8287.2006.tb00312.x

Kellerman A (1978) Determinants of rent from agricultural land around metropolitan areas. Geographical Analysis 10:1-12. https://doi.org/ 10.1111/j.1538-4632.1978.tb00641.x

Keys PW, Wang-Erlandsson L, Gordon LJ (2016) Revealing invisible water: moisture recycling as an ecosystem service. PLoS ONE 11: e0151993. https://doi.org/10.1371/journal.pone.0151993

Kleinpenning JM (1983) The integration and colonisation of the Paraguayan Chaco. Nijmeegse geografische cahiers, vol 24. Geografisch en Planologisch Inst. Kath. Univ, Nijmegen

Komarek AM, de Pinto A, Smith VH (2020) A review of types of risks in agriculture: what we know and what we need to know. Agricultural Systems 178:102738. https://doi.org/10.1016/j.agsy.2019.102738

Kuemmerle T, Altrichter M, Baldi G, Cabido M, Camino M et al. (2017) Forest conservation: remember Gran Chaco. Science 355:465. https://doi.org/10.1126/science.aal3020

La Nación (2017) USDA proveerá materiales para estudio de la soja en el Chaco. https://www.lanacion.com.py/negocios edicion impresa/ 2017/12/27/usda-proveera-materiales-para-estudio-de-la-soja-en-elchaco. Accessed 6 Jul 2020

La Nación (2019) Abdo prometió una inversión de US\$2.500 millones en el Chaco. https://www.lanacion.com.py/politica_edicion impresa/2019/08/18/abdo-prometio-una-inversion-de-us-2500millones-en-el-chaco. Accessed 16 Feb 2020

Lambin EF, Meyfroidt P (2011) Global land use change, economic globalization, and the looming land scarcity. Proc Natl Acad Sci U S A 108:3465-3472. https://doi.org/10.1073/pnas.1100480108

Le Polain de Waroux Y, Garrett RD, Heilmayr R, Lambin EF (2016) Land-use policies and corporate investments in agriculture in the Gran Chaco and Chiquitano. Proc Natl Acad Sci U S A 113: 4021-4026. https://doi.org/10.1073/pnas.1602646113

Le Polain de Waroux Y, Garrett RD, Graesser J, Nolte C, White C, Lambin EF (2017) The restructuring of South American soy and beef production and trade under changing environmental Regulations. World Development. https://doi.org/10.1016/j. worlddev.2017.05.034

Le Polain de Waroux Y, Baumann M, Gasparri NI, Gavier-Pizarro G, Godar J, Kuemmerle T, Müller R, Vázquez F, Volante JN, Meyfroidt P (2018) Rents, actors, and the expansion of commodity frontiers in the Gran Chaco. Annals of the American Association of Geographers 108:204-225. https://doi.org/10.1080/24694452. 2017.1360761

Lima LS, Coe MT, Soares Filho BS, Cuadra SV, Dias LC et al. (2014) Feedbacks between deforestation, climate, and hydrology in the Southwestern Amazon: implications for the provision of ecosystem services. Landscape Ecol 29:261-274. https://doi.org/10.1007/ s10980-013-9962-1

Meyfroidt P, Carlson KM, Fagan ME, Gutiérrez-Vélez VH, Macedo MN et al. (2014) Multiple pathways of commodity crop expansion in tropical forest landscapes. Environ. Res. Lett. 9:74012. https://doi. org/10.1088/1748-9326/9/7/074012

Meyfroidt P, Börner J, Garrett R, Gardner T, Godar J, Kis-Katos K, Soares-Filho BS, Wunder S (2020) Focus on leakage and spillovers: 
informing land-use governance in a tele-coupled world. Environ. Res. Lett. 15:90202. https://doi.org/10.1088/1748-9326/ab7397

Morgan D (2008) Snowball Sampling. In: Given L (ed) The SAGE encyclopedia of qualitative research methods: snowball sampling. SAGE Publications, Inc, 2455 Teller Road, Thousand Oaks California 91320 United States

Morton DC, DeFries RS, Shimabukuro YE, Anderson LO, Arai E, del Bon E-SF, Freitas R, Morisette J (2006) Cropland expansion changes deforestation dynamics in the southern Brazilian Amazon. Proc Natl Acad Sci U S A 103:14637-14641. https://oi.org/10.1073/ pnas.0606377103

National System of Wild Protected Areas of Paraguay Act (SINASIP): Law 352/94 (1994)

Neufeld E (2018) Se viene la Soja. Green Commodities / Plataforma Regional de Carne Sostenible, Filadelfia, Paraguay

Nolte C, Le Polain de Waroux Y, Munger J, Reis TN, Lambin EF (2017) Conditions influencing the adoption of effective anti-deforestation policies in South America's commodity frontiers. Global Environmental Change 43:1-14. https://doi.org/10.1016/j. gloenvcha.2017.01.001

Ochoa-Quintero JM, Gardner TA, Rosa I, Ferraz SF, Sutherland WJ (2015) Thresholds of species loss in Amazonian deforestation frontier landscapes. Conserv Biol 29:440-451. https://doi.org/10.1111/ cobi.12446

Pacheco P (2012) Actor and frontier types in the Brazilian Amazon: assessing interactions and outcomes associated with frontier expansion. Geoforum 43:864-874. https://doi.org/10.1016/j.geoforum. 2012.02.003

Paraguayan Ministry of Public Works and Communications (2020) Bioceánica se adelanta y suma otros $14 \mathrm{~km}$ de carretera: 11/02/ 2020, Asuncion, Paraguay

Passerieu C (2018) Marco Teórico del Cultivo de Soja en el Chaco. Green Commodities/Plataforma Regional de Carne Sostenible, Filadelfia, Paraguay

Pendrill F, Persson UM, Godar J, Kastner T (2019) Deforestation displaced: trade in forest-risk commodities and the prospects for a global forest transition. Environ. Res. Lett. 14:55003. https://doi. org/10.1088/1748-9326/ab0d41

Pezzoli A, Ponte E (2016) 4. Vulnerability and resilience to drought in the Chaco, Paraguay. In: Tiepolo (ed) Planning to cope with tropical and subtropical climate change. De Gruyter, Warsaw, Poland

Pfaff A, Robalino J, Walker R, Aldrich S, Caldas M, Reis E, Perz S, Bohrer C, Arima E, Laurance W, Kirby K (2007) Road investments, spatial spillovers, and deforestation in the Brazilian Amazon. J Regional Sci 47:109-123. https://doi.org/10.1111/j.1467-9787. 2007.00502.x

Piquer-Rodríguez M, Butsic V, Gärtner P, Macchi L, Baumann M, Gavier Pizarro G, Volante JN, Gasparri IN, Kuemmerle T (2018) Drivers of agricultural land-use change in the Argentine Pampas and Chaco regions. Applied Geography 91:111-122. https://doi.org/10. 1016/j.apgeog.2018.01.004
RCC (2020) El cultivo de la soja alcanzaría en el Chaco las 48.000 hectáreas esta temporada. Red Chaqueña de Comunicaciones

Redo D, Millington AC, Hindery D (2011) Deforestation dynamics and policy changes in Bolivia's post-neoliberal era. Land Use Policy 28: 227-241. https://doi.org/10.1016/j.landusepol.2010.06.004

Schielein J, Frey G, Miranda J, Souza R, Börner J, Henderson J (2021) The role of accessibility for land use and land cover change in the Brazilian Amazon. Applied Geography

Strassburg BBN, Brooks T, Feltran-Barbieri R, Iribarrem A, Crouzeilles R, Loyola R, Latawiec AE, Oliveira Filho FJB, Scaramuzza CAM, Scarano FR, Soares-Filho B, Balmford A (2017) Moment of truth for the Cerrado hotspot. Nat Ecol Evol 1:99. https://doi.org/10.1038/ s41559-017-0099

Teodoro PE, de Oliveira-Júnior JF, da Cunha ER, Correa CCG, Torres FE, Bacani VM, Gois G, Ribeiro LP (2016) Cluster analysis applied to the spatial and temporal variability of monthly rainfall in Mato Grosso do Sul State, Brazil. Meteorol Atmos Phys 128:197-209. https://doi.org/10.1007/s00703-015-0408-y

Turner FJ (1920) The frontier in American history. Henry Holt, New York

Turzi M (2017) The political economy of agricultural booms: managing soybean production in Argentina, Brazil, and Paraguay, 1st edn. Springer International Publishing, Cham

Ultima Hora (2019) Corredor Bioceánico se prepara para el tránsito de cargas. https://www.ultimahora.com/corredor-bioceanico-seprepara-el-transito-cargas-n2838322.html. Accessed 16 May 2020

Vázquez F (2013) Geografía humana del Chaco paraguayo: Transformaciones territoriales y desarrollo regional, 1 st edn. ADEPO, Asuncíon

Veit P, Sarsfield R (2017) Land rights, beef commodity chains, and deforestation dynamics in the Paraguayan Chaco. USAID, Washington, DC

Volante JN, Mosciaro MJ, Gavier-Pizarro GI, Paruelo JM (2016) Agricultural expansion in the semiarid Chaco: poorly selective contagious advance. Land Use Policy 55:154-165. https://doi.org/10. 1016/j.landusepol.2016.03.025

World Bank Group (2017) Commodity prices - history and projections 1960-2030. https://datacatalog.worldbank.org/dataset/commodityprices-history-and-projections. Accessed 21 May 2020

Yanosky A (2013) Paraguay's challenge of conserving natural habitats and biodiversity with global markets demanding for products. In: Raven PH, Sodhi NS, Gibson L (eds) Conservation Biology. John Wiley \& Sons, Ltd, Oxford, UK, pp 113-119

Zero Deforestation Law: Law 2524/04 (2004)

Zoomers A, Goldfarb L (2013) The drivers behind the rapid expansion of genetically modified soya production into the Chaco Region of Argentina. In: Fang Z (ed) Biofuels - Economy. Environment and Sustainability, InTech

Publisher's note Springer Nature remains neutral with regard to jurisdictional claims in published maps and institutional affiliations. 